\title{
Influence of Current Asset Structure on Financial Performance of Manufacturing Firms in the Building and Construction Sector in Kenya
}

\author{
Author 1: Muli, B. M.: Jomo Kenyatta University of Agriculture and Technology* \\ Author 2: Muturi, W.M.: Jomo Kenyatta University of Agriculture and Technology \\ Author 3. Wepukhulu, J. M.: Jomo Kenyatta University of Agriculture and Technology \\ "Corresponding Author email: bernardmulako@gmail.com
}

The research is sponsored by Bernard Muli and Jomo Kenyatta University of Agriculture and Technology

\section{Abstract}

All business organizations including those in the building and construction sector are always concerned about their financial performance. This is usually with respect to how their operating, investing and financing activities not only help generate revenues but also how to keep the costs of all this operations down so as to optimize on business profitability. Despite the concern for financial performance in general and profitability in particular, it is still not clear how the current assets structure (that reflects business policy on management of current assets) affect the financial performance of companies in the building and construction sector in Kenya. The variations in the asset management policies across the industry is reflected in the variations in the asset structure ranging from very low current asset to total asset ratios to very high of these ratios. Despite the variations in the current asset management policies, there is lack of empirical and theoretical clarity as to how the current asset structure influences profitability of these companies. Empirically, extant research arrives at conflicting findings as to how asset management is related to financial performance. Theoretically, whereas the portfolio theory of Markowtz (1952) recommend optimal asset structuring to minimize risk and therefore boost performance, the agency theory of Jensen and Meckling (1976) on the other hand fail to pinpoint a clear association between the current asset structure and financial performance. The trade-off theory of Gitman (1974) implies inverse relationship between liquidity and profitability. This study is designed as a causal exploratory survey using the largest 44 companies in the building and construction sector in Kenya over a 5 year period covering 2016 to 2021. This forms 220 firm-year observations. Fixed effects bivariate panel regression model was adopted after conducting model specification tests. The test of hypothesis was conducted using the t-statistic at $95 \%$ confidence interval. Based on the positivist research philosophy, the findings reveal that current asset structure (CAS) as measured by the current asset to total assets ratio had a negative effect on financial performance as measured by return on equity and net profit margin. This supports the optimal asset structuring to balance off the risk return trade-off. The study was limited to the large firms in the building and construction sector and recommends an enhanced sample for all company sizes to check out if size has an effect on the robustness of the findings.

Keywords: Current Asset Structure; Financial Performance; Profitability

DOI: $10.7176 /$ RJFA/13-4-03

Publication date: February $28^{\text {th }} 2022$

\section{I.Introduction}

Asset management is a subset of financial management (Lakew \& Rao, 2014). Financial management is one of the several functional areas of management which is center to the success of any business. It involves planning, organizing, coordinating and controlling the financial resources of a business and how they are deployed to achieve organizational success. In a nutshell it revolves around the decisions of financial managers with respect to capital budgeting, financing, working capital, dividend, capital structure and risk management decisions. Inefficient financial management, combined with the uncertainty of the business environment often lead business enterprises to serious problems (Lakew \& Rao, 2014). In essence, businesses may institute financial management decisions aimed at boosting their financial performance.

According to Yohanes, Lemie and Shibru (2018), careless asset management practices are the main causes of poor financial performance and failure of business enterprises. Regardless of whether it is an owner-manager or hired-manager, if the asset management decisions and practices are wrong, profitability of the company could be adversely affected and consequently, the entire business organization (Lakew \& Rao, 2014). Lakew and Rao (2014) state that the practices adopted for managing the mix of the non-current and current assets are critical because they have risk and return implications. Whereas non-current assets lead to high returns, they are usually more risky because of the difficulty of converting them into liquid form for day to day operations. Current assets on the other hand are less risky because they are in cash or near cash spendable form, but they portend very minimal returns for the business (Lakew \& Rao, 2014).

The management of assets and the related asset structures is aimed at optimizing the trade-off between the 
risks and returns of holding these assets. These relate to the structure of the current assets, the structure of the noncurrent assets, the asset holding periods, the turnover of assets, the mix of the current and non-current assets, the asset conversion period and the financing of these assets. All these should aim at minimizing the risk of holding the assets while maximizing their return as articulated by the Markowitz (1952) model and its subsequent modifications for optimal portfolio mix. It is in this perspective that the element of asset structure comes in. Asset structure can easily be identified as the proportionate components of the various categories of assets in the total assets available to the firm. These include current assets, non-current assets on one side and tangible assets and intangible assets on the other hand (Yohanes, Lemie \& Shibru, 2018).

Both current asset and non-current asset management relate to the choices made by top level management in the firm regarding the portfolio choices of the mix current assets and current liabilities and the related risks and returns (McLaney, 2017). Top management considers the available assets appraises and them to ensure that the return of the ones undertaken is higher than their costs. They involve investment in capital projects for long term generation of returns and well as investment in liquid assets for operations. When making the asset mix portfolio decisions, the decision makers decide whether adding the assets of the firms today will enhance the revenues of the firms in the future to cover the capital costs and other expenses from the assets (Zada et al., 2019). According to McLaney (2017), key considerations in the asset structure decision making include risk, return, costs, timing of cash flows and costs and financing sources.

The attitude towards risk and the risk profile is reflected in the asset structure adopted by the business (Ukhriyawati, Ratnawati \& Riyadi, 2017). There are three main strategies that can be used in the financing of assets using the available liabilities. These are the aggressive approach, the hedging approach and the conservative approach (Ukhriyawati, Ratnawati \& Riyadi, 2017). In the aggressive approach that defines companies that have risk taking managers, most of the assets are financed using current liabilities. The cost is low but the risk of failure to fulfil the attendant financial obligations is quite high. In the hedging approach, the management is likely to carry out practices that involve balancing off the terms of the liabilities and those of assets. In this respect, current assets are financed using current liabilities while non-current assets are financed using non-current liabilities. On the extreme side is the risk averse approach, where the management wishes to avoid risk of failure as much as possible such that they finance most of the assets using the less risky long term liabilities.

Asset management decisions and the resultant asset structures are critical to the success of any firm. Arasa and Waititu (2014) observe that investment decisions are vital to a firm's financial wellbeing and are among the most important decisions that owners or managers of a firm must make. Their rationale for that belief is that capital budgeting decision often involves significant capital outlay to acquire non-current assets and this has an opportunity cost on the proportion of current assets at the disposal of an organization. Kinyanzii, Ombuki and Kalii (2014) observe that the use of sophisticated asset mix portfolio decisions for optimal capital assets and liquid assets portfolio mix are bound to have a profound positive influence on the financial performance of a business given the risk-return implications of the assets' matrix.

Current asset structure reflects the value of current assets with respect to the entire asset portfolio of the business. This structure is critical because of the risk return implications because theoretically current assets are required for smooth daily operations of a business but are largely non-return generating as explicitly expounded by Seru and Sufi (2021). From this theoretical perspective there may be a need for a trade-off between a low proportion of current assets in the asset mix and a high proportion of the same. This may be a function of the risk profile of the business where risk seeking firms may go for long term assets while risk averse one hold greater proportions of liquid assets (Seru \& Sufi, 2021). From this perspective, it is not clear how current asset structure affects financial performance as expounded in the following section of the paper.

\section{Literature and Hypothesis Development}

Three approaches to literature are evaluated in this section all culminating in the hypothesis of the study. This are the conceptual, theoretical and empirical approaches to literature. From a conceptual perspective, asset structure simply defines the relative proportions of various categories of assets in the business (Seru $\&$ Sufi, 2021). Taken to its logical conclusion this definition implies that of the various categories of assets identified by Oluoch (2014), each can be related to the other or the total and all these would remain valid concepts of asset structure. Oluoch (2014) identifies assets as current assets, non-current assets, intangible assets and tangible assets. Accordingly one can conceptualize current assets as a proportion of total assets; noncurrent assets as a proportion of total assets; either of these two as a proportion of each other or intangible assets as a proportion as a proportion of total assets; tangible assets as a as a proportion of total assets or either of these two as a proportion of each other. Due to the need for mutual exclusivity, this study adopts current assets as a proportion of total assets as recommended by Blume and Friend (1975).

From the theoretical angle, there are numerous theories that try to explain how asset structure can relate to the financial performance of a business. The agency theory of Jensen and Meckling (1976) fail to pinpoint a clear association between the current asset structure and financial performance. Its theoretical assumptions imply that 
managerial self-interests and their clash with owners' wealth maximization interests may produce an asset structure that is wide and varied in line with how well these interests are aligned. The effect is that managerial tendency to be influenced by private interests may make poor profit management decisions like earnings management which ultimately would influence how asset structure relates to financial performance. That since managers are in charge of both asset structuring and financial performance reporting, they can influence either or both to their private advantage making it difficult to tell how the two relate.

A contradictory theory is the trade-off theory which argues that the way a firm structures its current assets and liquidity has an implications on the choice between sacrificing profitability at the expense of liquidity (Gitman, 1974). Excess current assets and the corresponding liquidity reduces the amount of resources available for generating returns given that current assets are largely non-return generating. In this theorization, a smart firm will only hold current assets for operations and would therefore have very low current asset to total assets ratio. Such a firm would have enhanced profitability as explained by Gitman (1974). Risk-return trade-off is an argument also articulated by Markowtz (1952) in the portfolio theory, albeit approached from a portfolio diversification perspective. This theory would mean that the more diversified the asset structure is in terms of the components of current, no-current, tangible and intangible assets, the lower the risk and therefore expected return.

The confounding conceptual and theoretical positions is also noted in the extant studies from around the globe. In Indonesia for instance, Nurlaela, Mursito, Kustiyah, Istiqomah and Hartono (2019) evaluated the interrelationship between asset management and financial performance using asset turnover as the indicator of asset management. The study was based on the fast moving consumer goods industry. It was based on a 3- year time framework covering the period 2016 through 2018. The quantitative research used regression analysis asset management both liquid assets and total assets had a positive effect on financial performance of these companies as listed on the Indonesia Stock Exchange.

In Germany, Czarnitzki and Hottenrott (2017) in a study to examine the relation between working capital management and profitability established that optimal working capital level helps to maximize profitability in businesses. In that regard, it is key for businesses to establish their optimal working capital level. Thevaruban (2016) in Thailand indicated that Small and medium enterprises are usually operated using capital provided by their owners, venture capitalists and angel investors as they are unable to use external fund with higher cost of capital in the early stages. The study further concluded that small scale industries in Thailand are difficult to get credit from external parties because the cash inflow and savings of the business in the small-scale sector is very low. This ultimately compromises their current asset structuring ability.

In Nigeria, Ogbeifun and Akinola (2018) investigated the influence of asset and liability management practices among commercial banks in Nigeria, which in the regulatory framework, they are also referred to as money banks. They aimed to find out the best practices in the administration of liabilities and assets within the Nigerian economy which is one of the strongest economies in Africa. The study emphasized on two theories the portfolio theory and the liability management theory both of which are closely intertwined with the asset and liability structuring practices. Relying on annual reports and the statistical bulletins by the Central bank of Nigeria, secondary data was collected for the study. Their findings indicated that assets are positively associated with profitability of banks.

In Kenya, Kiita (2013) indicated that on overall, financial performance is positively affected by the financial management practices that include asset structuring practices. In that regard, to enhance organizational performance, financial management practices revolving around decisions like capital structure decision, dividend policy, investment appraisal techniques, working capital management and financial performance assessment should be well managed in all organizations disregarding its level of sophistication. Nthenge and Ringera (2017) highlighted that financial management is an important element of the management of any business. In that, regard, they highlighted that working capital management; investment decisions and financial decisions influence financial performance positively.

Kinyariro, Gesami and Kirimi (2017) established that asset and liability management decisions as encapsulated within financial management decisions significantly influence the financial stability of football clubs. The study also indicated that with a well-articulated financial management structure football clubs would improve their performance not only on the pitch but also on the financial perspective of the clubs.

From the contextual angle, the Competition Authority of Kenya, CAK (2017) notes that Kenya is in this period undergoing rapid expansion in the construction and building sector. According to CAK (2017), the construction and building boom is attributed to the rapid growth in Kenyan population from 39 million people in 2009 to a figure that has topped 50 million in 2021. In addition, the construction sector had hitherto been underdeveloped and it the boom is an inevitable consequence of the increasing modernization of the sector. CAK (2017) further notes that in 2015, the sector delivered a massive growth of $13.6 \%$ with respected to value addition. The growth however declined to $9.2 \%$ in the year 2016. Within Nairobi County, CAK (2017) shows that new private buildings grew from 70.9 billion shillings in 2015 to $76 ., 2$ billion in the subsequent year. In a summary, CAK (2017) notes that the construction sector in Kenya is regulated by the National Construction Authority. 
A well-developed and evolved cement industry is a boon for economic development as it provides long- term funds for infrastructure development of every economy (Charumathi, 2012). In the context of business entities, accounting information is important as it can help the firms manage their short-term financial problems in critical areas like costing, expenditure and cash flow, by providing information to support monitoring and control. At all levels of organizations, budgets are getting tighter and there is an increased need for financial management initiatives to directly contribute to providing timely, accurate, reliable financial information to support management decisions (McLaney, 2017).

While focusing on cash flow management only, Ndungu and Oluoch (2016) evaluated their influence on market performance of public construction companies in Kenya. For a seven year period, the study evaluated how operating, free, financing and investing cash flow management affected market returns of this companies using the modified capital asset pricing model (CAPM) based on 70 semi-annual observations of the five public companies that market segment. The findings revealed that whereas the cash flows from operations are positively associated with market returns, those from investing, financing as well as free cash flows negatively affected market returns. In a nutshell, management of cash flows have an effect of the market performance of public construction companies in Kenya.

It is from the foregoing that the statement of the problem for this research merges. In this respect, all business organizations including those in the building and construction sector are always concerned about their financial performance. This is usually with respect to how their operating, investing and financing activities not only help generate revenues but also how to keep the costs of all this operations down so as to optimize on business profitability. Despite the concern for financial performance in general and profitability in particular, it is still not clear how the current assets structure (that reflects business policy on management of current assets) affect the financial performance of companies in the building and construction sector in Kenya. The variations in the asset management policies across the industry is reflected in the variations in the asset structure ranging from very low current asset to total asset ratios to very high of these ratios.

There is also a market performance problem that compounds the research problem. That despite the growth in the building and construction sector which has enhanced the demand for construction materials, manufacturing firms in the building and construction sector in Kenya continue to experience erratic financial performance. Despite the unprecedented growth rates in the building and construction sector in Kenya, fueled by the economic policy of the government and the rapidly growing populations, the financial performance of firms in the construction industry has been erratic with mixed results from the industry ranging from negative profitability, flat performance to very high financial performance. In addition to the erratic profitability, evidence from the industry reveals that the growth last part of the second decade of this millennium has been decreasing. The building and construction sector registered a slower growth rate of 5.9\% in 2019, 6.3 percent in 2018 and 8.5 per cent in 2017 the previous year (Kenya National Bureau of Statistics, 2019).

The confounding literature leads to the postulation that it is not clear how current asset structure affects financial performance of manufacturing companies in the building and construction sector in Kenya. This is presented as:

Ho: Current assets structure has no significant influence on financial performance of manufacturing firms in the building and construction sector in Kenya

Using return on equity (ROE) as the dependent variable and current asset structure (CAS) as indicated by the ratio of current asset to total assets as the independent variable, this hypothesis can be mathematically be shown that in a bivariate relationship of ROE and CAS, then the coefficient of CAS is not significantly different from zero

$$
H_{0}=\beta_{1} C A S_{i, t} \approx 0
$$

The findings of study contributes to the knowledge of financial performance of manufacturing firms in the building and construction sector in Kenya. The findings of financial performance of manufacturing firms in the building and construction sector in Kenya in this study expands the literature of financial management decisions in general and especially on financial performance of manufacturing firms in the building and construction sector in Kenya. The findings of the study offer valuable contributions from both a theoretical and practical standpoint where it contributes to the general understanding of the role of financial performance of manufacturing firms in the building and construction sector in Kenya.

\section{Methodology}

The study is oriented in the positivism philosophy which in the context of this study as per Aliyu, Bello, Kasim and Martin (2014) espouses the scientific approach to design that started from problem identification that it is clear how current asset structure influences financial performance of companies in the building and construction industry. This was then conceptualized based on literature review before hypothesis testing was done. Exploratory causal research design is utilized. This is deemed appropriate since it first of all explores the interrelationship between asset structure and financial performance in the building and construction industry and second, there is 
an expected causal relationship as specified in the research hypotheses.

The study relies on a purposive sampling of all the large building and construction industry companies using their annual turnover (sales income) as the indicator of size. The large companies were chosen because of availability of published financial statements from internal and regulatory sources since the study relied on these statements for collection of secondary data used. The data in this case was collected using a secondary data collection sheet and it included the sales turnover, the earnings after tax (EAT), shareholders' equity, the current assets and the total assets. The time scope of the study was 5 years covering 2016 to 2020 .

A bivariate panel regression model was used in the analysis as specified in the model 1.

$$
\begin{aligned}
& R O E_{i, t}=\beta_{0}+\beta_{1} C A S_{i, t}+e_{i, t}-------- \text { (1) }
\end{aligned}
$$

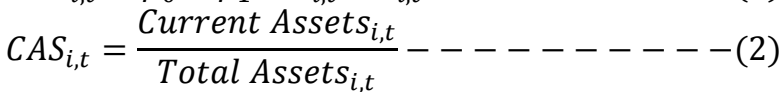

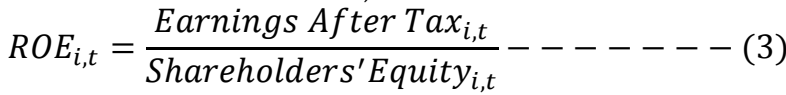

The identification of the best panel data to use for the study was based on model specification tests in choosing between fixed effect and random effects study model. The testing of hypothesis was done at $95 \%$ confidence interval using the t-statistic and the p-value at 0.05 level of significance. This was for the purposes of inferential statistical analysis and was done after the descriptive statistical analysis.

\section{Findings and Discussion}

The findings in the study are established at two levels. This is the descriptive level and the inferential level. The descriptive statistical findings are provided in table 1 for both Return on Equity (ROE) and current asset structure (CAS) as indicated by the ratio of current assets to total assets. With respect to current assets, the minimum proportion of current assets in the structure is $28.5 \%$ while the maximum is $60.0 \%$ percent. The mean is presented as $35.9 \%$.

Table 1: Summary Statistics, observations 1:1 - 44:5 (220 observations)

\begin{tabular}{ccccccc}
\hline Variable & Mean & Median & Minimum & Maximum & Std. Dev & C. . \\
\hline $\boldsymbol{R O E}$ & 0.11968 & 0.11994 & -0.13583 & 0.17425 & 0.025915 & 0.21653 \\
\hline $\boldsymbol{C A S}$ & 0.35938 & 0.36006 & 0.28527 & 0.60014 & 0.031603 & 0.08794 \\
\hline
\end{tabular}

For the current asset structure, the results are consistent with those of Yahaya, Kutigi, Solanke, Onyabe and Usman (2015) noted that investment in current assets is wide and varied but manufacturing firms have heavier investment in current assets especially with respect to inventories and receivables. With a standard deviation of 0.031603 , it translates to a coefficient of variation $(\mathrm{CV})$ of 0.08794 indicating a very stable level of the structures across the industry that for every unit of CAS, there was bound to be a periodic deviation of only 0.09 over time and cross-sectionally.

For return on equity, the returns range from a loss of $13.58 \%$ (the minimum) to a profit of $17.43 \%$ (the maximum) having registered a mean of $11.97 \%$. The relatively low level of profitability could be attributed to the high cost of doing business in Kenya especially with respect to manufacturing as has also been registered by Were (2016) who underscored the high cost of production given the high cost of direct inputs and production overheads. The Kenya Chamber of Commerce and Industry (2021) has also given this as the biggest concern for the manufacturing sector in Kenya. The findings on ROE also indicate high levels of volatility as shown by the CV of 0.2165 which is almost triple that of CAS.

Inferential analysis involved firstly testing the panel data assumptions and then carrying out test of hypothesis as well as correlation analysis. The findings are indicated in Table 2. 
Table 2: Included 44 cross-sectional units Time-series length $=5$ (220 Observations) Dependent variable: ROE

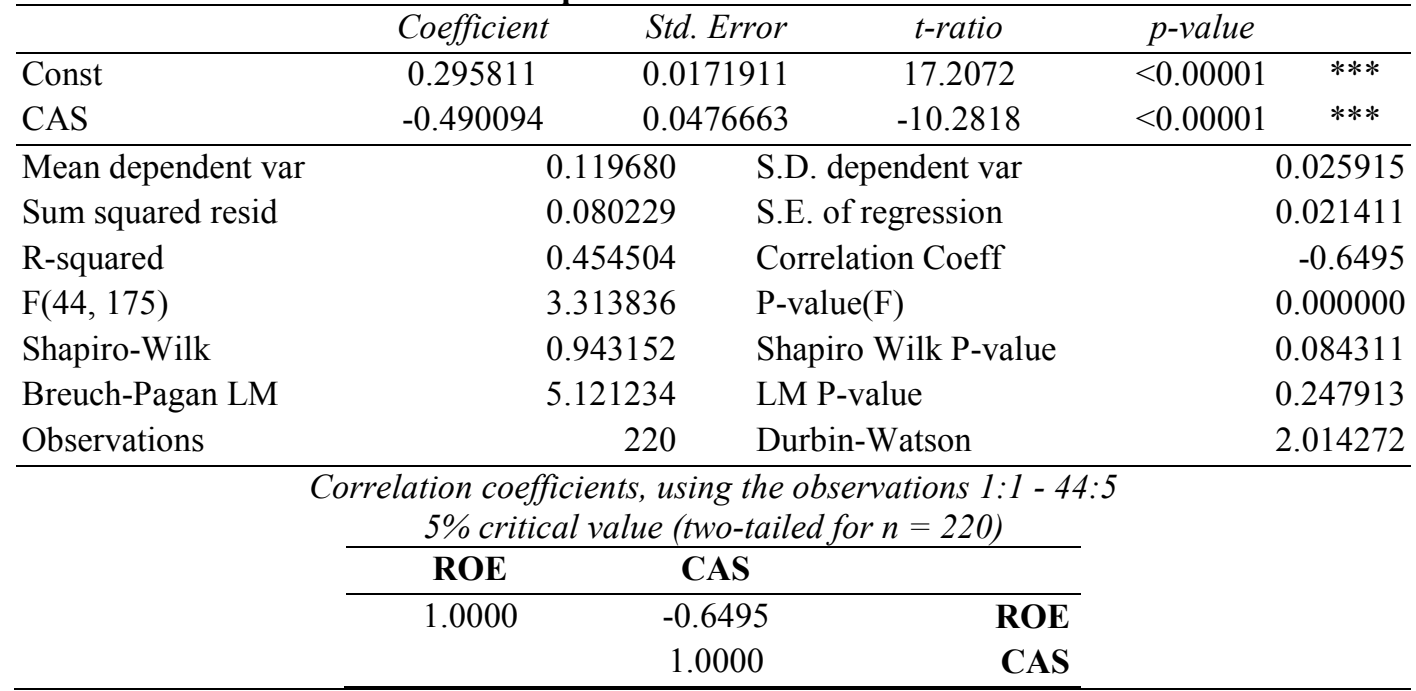

At the first level Shapiro-Wilk Statistic was used for checking normality and with value of 0.943152 and a pvalue of 0.084311 being higher than the critical value of 0.05 , the data is normally distributed. With respect to heteroscedasticity, Breuch-Pagan LM was used and its p-value of 0.247913 indicates that the model upholds the homoscedastic expectations. With respect to serial correlation, the Durbin-Watson d-value of 2.014 is approximately 2 thereby indicating a data absence of statistically significant autocorrelation as is articulated by Gujarati (2011). The stability of the model in carrying out the analysis is checked using the model F-test. This provides an F-value of 3.313854 which is greater than the significant F-value of 0.000 . This indicates that the model is suitable for analysis as suggested by Gujarati (2011).

The model provides an R-squared value of 0.454504 an indicator that $45.4 \%$ of the changes in ROE are explained by the variations in CAS while the remainder of the variations are attributable to other factors outside of this independent variable. This is expected because studies like that of Wamiori (2019) have identified numerous factors that affect financial performance of manufacturing companies in Kenya. Wamiori (2019) for instance identified these factors as access to finance; cost of capital; level of competition; fiscal tax incentives and investment practices of the manufacturing firms. In Pakistan, Mirza and Javed (2013) identify other factors as corporate governance; risk management; ownership structure and capital structure. Given all these multitude of factors, the reported coefficient of determination in this study is acceptable.

The null hypothesis presented in the study is that current asset structure has no significant effect on financial performance of companies in the building and construction sector in Kenya. The findings presented in the table 2. The results show a CAS coefficient of -0.490094 . The corresponding t-statistic for a two tailed test at $95 \%$ confidence interval and 219 degrees of freedom is 10.2818. This is greater than a two tailed critical value of 1.9709. This leads to the rejection of the hypothesis and the conclusion that current asset structure has a negative effect on financial performance and that the higher the ratio of current assets to total assets the poorer the financial performance and vice versa. This position is supported by the p-value which is less than 0.00001 at 0.05 level of significance. In line with Gujarati (2011) whenever the output t-value is greater than the level of significance, reject the null hypothesis and assume the output effect.

The takeaway from the bivariate panel evaluation is that there is an inverse relationship between CAS and financial performance. This is evident also from the coefficient of correlation that is indicated in table 2 between CAS and ROE (the indicator of financial performance). This is perfectly in line with the trade-off theory of asset management of Gitman (1974) high liquidity corresponds with low profitability and vice versa. The implication as per Markowitz (1952) is that there is need for risk return balance. Seru and Sufi (2021) indicate that whereas current assets are necessary for operations, they concurrently are accompanied by low returns since they are largely non-return generating. This implies that one needs to have an optimum level of current assets to ensure smooth operations while simultaneously not incurring high opportunity costs of locked in resources that could be applied to high-return generating assets. As per the position noted by Ukhriyawati, Ratnawati and Riyadi (2017) that the three asset management approaches of aggressive, hedging and conservative have varying risk-return implications.

The findings from this study can be compared with empirical findings from other similar studies. Al-Ani (2013) for instance evaluated the effect of asset structure on financial performance of companies in Oman and found out that current asset structure has no significant effect on profitability. This contracts the findings in this study yet it could be because the metrics used by Al-Ani (2013) to measure asset structure was total asset turnover. The result is that turnover has an element of revenue which is also reflected in return on equity. This could have 
influenced the findings. More so, Oman is structurally different from the industry structure of companies in the Kenyan building and construction sector. Also contradicting the findings albeit in the opposite direction are the findings of Koech, Muturi and Oluoch (2021) who while focusing only on inventory structure among the nonfinancial public firms listed at the Nairobi Securities Exchange (NSE) found a positive relationship between current assets structure (inventory) and financial performance. This finding could be explained by the sole focus on inventory to the exclusion of other current assets.

The findings from this study however closely mirror those of Yahaya et al. (2015) who found that current assets negatively affected the performance of Nigeria commercial banks. This similarity could stem from the closeness in operations structure among Nigerian and Kenyan companies since all of them are identified as commonwealth countries. It is however noteworthy that the Yahaya et al. (2015) study was based on banks while this study is based on manufacturing companies in the construction and building sector in Kenya. This is in contradiction of Al-Slehat, Zaher, Fattah and Box (2020) who found a positive association between firm value and asset structure. The difference however is that firm value is an indicator of market performance as opposed to ROE that indicates financial performance.

\section{Conclusion}

The study was carried out over a five year period of 2016 to 2020 and was based on panel data analysis to establish how asset structure affects financial performance of firms in the building and construction industry in Kenya. The sample was purposively based on the largest 44 firms in this sector because of the availability of data which formed 220 firm year observations. The null hypothesis that the current asset structure has no significant influence on financial performance was rejected with the conclusion that it bears a negative effect on the financial performance of the firms. The finding seemed to agree with the theoretical exposition of Gitman (1974) that the trade-off between profitability and liquidity inevitably implies that firms that hold excessive current assets would be characterized by low levels of profitability and vice versa.

The study was adequate in establishing how current asset structures affected the performance of manufacturing companies in the building and construction industry. The study was however faced by a number of limitations. First, the study focused purely on the manufacturing companies in the construction and building sector in Kenya. Accordingly, the findings are specific to this sector and do not include other critical sectors of the economy. This however was not deemed too limiting and the findings are generalizable to similar homogenous segments of the economy. In addition, the design is limited to exploratory causal survey. This was necessary in order to use the secondary data collected from financial statements data as indicators of the structures that are used to manage assets. This was however deemed not too limiting because the diagnostic tests necessary for panel regression were used and all the necessary data adjustments made. Further, the performance data was collected over a long period of time of five years which was adequate to smooth out the fluctuations in earnings as opposed to single year performance information.

Thirdly, the study was limited to Kenya as a geographical region. This means that the findings are generalizable for the country but may not be done across the border. It should however be noted that Kenya has unique economic and regulatory fundamentals, and that a country with similar fundamentals can have the findings being generalizable to such jurisdiction. In any case, the findings being unique to Kenya can form a basis of comparing and contrasting with empirical findings from other regulatory regimes that are distinctly different so as to broaden the knowledge scope.

Finally, the study was limited in conceptual scope but focusing on one category of asset structure and one indicator of financial performance. A multiple variable situation could bring out other empirical elements not sufficiently catered for in this study. In light of this it is recommended that a similar study be undertaken with a keen analysis of a multiple number of asset structures and even liability structures. This can be expanded to include a wide section of companies besides the largest companies in the building and construction sector. This could also be expanded to include other sectors in Kenya.

\section{REFERENCES}

Al-Ani , M. K. (2013). Effects of assets structure on the financial performance: Evidence from sultanate of Oman. In 11th EBES Conference proceedings in Ekaterinburg, Russia (pp. 147-165).

Aliyu, A. A., Bello, M. U., Kasim, R., \& Martin, D. (2014). Positivist and non-positivist paradigm in social science research: Conflicting paradigms or perfect partners. J. Mgmt. \& Sustainability, 4, 79.

Al-Slehat, Z. A. F., Zaher, C., Fattah, A., \& Box, P. O. (2020). Impact of financial leverage, size and assets structure on firm value: Evidence from industrial sector, Jordan. International Business Research, 13(1), 109-120.

Arasa, R., \& Waititu, A. (2014). Effect of Financial Management practices on Effectiveness of working capital management. International Journal of Social Sciences and Infromation Technology, 1(9), 1-10.

Blume, M. E., \& Friend, I. (1975). The asset structure of individual portfolios and some implications for utility functions. The Journal of Finance, 30(2), 585-603. 
Charumathi, B. (2012, July). On the determinants of profitability of Indian life insurers-an empirical study. In Proceedings of the world congress on Engineering (Vol. 1, No. 2, pp. 4-6). London.

Competition Authority of Kenya- CAK (2017). Kenya and the Construction Report. Retrieved from http://www.cak.go.ke. Accessed 21.11.2021

Czarnitzki, D., \& Hottenrott, H. (2017). R\&D investment and financing constraints of small and medium sized firms. Small Business Economics, 36(1), 65-83.

Gitman, L.J. (1974). Estimating corporate liquidity requirements: a simplified approach. The Financial Review, 9(1), pp. 79-88. doi: http://dx.doi.org/10.1111/j.1540-6288.1974. tb01453.x.

Gujarati, D. N. (2011). Econometrics by example (Vol. 1). New York: Palgrave Macmillan.

Jensen, M. C., \& Meckling, W. H. (1976). Theory of the firm: Managerial behavior, agency costs and ownership structure. Journal of financial economics, 3(4), 305-360.

Kenya Chamber of Commerce and Industry (2021)

Kiita, G. K. (2013). The relationship between financial management practices and financial performance in the shipping industry in Kenya (Doctoral dissertation, University of Nairobi).

Kinyanzii, J. M., Ombuki, C., \& Kalii, F. (2014). The Effect of Strategic Management Decisions on Performance of Public Secondary Schools in Mwatate Sub-County. Journal of Economics and Finance, 4(10), 13-47.

Kinyariro, D. K., Gesami, R., \& Kirimi, E. (2017). Relationship between financial management decisions and financial stability of football clubs in kenya a case of football clubs at Kenya Premier League. International Journal of Economics, Commerce and Management, V(8), 614-633.

Koech, D. J., Muturi, W., \& Oluoch, O. (2021). Effect of Current Assets Management on Financial Performance of Non-Financial Firms Listed at Nairobi Securities Exchange.

Lakew, D. M., \& Rao, P. D. P. (2018). Effect of financial management decisions and characteristics on profitability: A study on business enterprises in Jimma Town, Ethiopia. National Monthly Refereed Journal of Research in Commerce \& Management, 2(5), 64-75.

Markowitz, H. (1952). The utility of wealth. Journal of political Economy, 60(2), 151-158.

McLaney, E. (2017). Business Finance: Theory \& Practice (11th ed.). London: FT / Prentice Hall.

Mirza, S. A., \& Javed, A. (2013). Determinants of financial performance of a firm: Case of Pakistani stock market. Journal of economics and International Finance, 5(2), 43-52.

Ndungu, B. W., \& Oluoch, O. (2016). Effect of cash flow management on market performance of public construction companies in Kenya. International journal of social Sciences and Information Technology, 2(8), $1-12$.

Nthenge, D. M., \& Ringera, J. (2017). Effect of financial management decisions on financial performance of small and medium enterprises in Kiambu Town, Kenya. American Based Research Journal, 6(1), 6-32.

Nurlaela, S., Mursito, B., Kustiyah, E., Istiqomah, I., \& Hartono, S. (2019). Asset Turnover, Capital Structure and Financial Performance Consumption Industry Company in Indonesia Stock Exchange. International Journal of Economics and Financial Issues, 9(3), 297.

Ogbeifun, I. E., \& Akinola, A. O. (2019). Impact of qualitative monetary policy on the performance of deposit money banks in Nigeria. International Journal of Development Research, 9(7), 28833-28840.

Oluoch (2014). College Introductory Financial Accounting. TPCL, Nairobi.

Seru, A., \& Sufi, A. (2021). Corporate finance (pp. 617-623). University of Chicago Press.

Thevaruban, J. S. (2016). Small scale industries and its financial problems in Thailand, Journal of Asia Entrepreneurship and Sustainability, 1, 66-74.

Ukhriyawati, C. F., Ratnawati, T., \& Riyadi, S. (2017). The influence of asset structure, capital structure, risk management, and good corporate governance on financial performance and value of the firm through earnings and free cash flow as an intervening variable in banking companies listed in Indonesia stock exchange. International Journal of Business and Management, 12(8), 249-260.

Wamiori, G. M. (2019). Determinants of Financial Performance of Manufacturing Firms in Kenya (Doctoral dissertation, JKUAT).

Were, A. (2016). Manufacturing in Kenya: Features, challenges and opportunities. International Journal of Science, Management and Engineering, 4(6), 15-26.

Yahaya, O. A., Kutigi, U. M., Solanke, A. A., Onyabe, J. M., \& Usman, S. O. (2015). Current assets management and financial performance: Evidence from listed deposit money banks in Nigeria. International Journal of African and Asian Studies, 13, 45-56.:

Yohanes, D., Lemie, K., \& Shibru, W. (2018). Effect of Financial Management Decisions on Profitability of SmallScale Enterprise: Case Study Hawassa City. Journal of Small Business Management, 20(6), 39-45. https://doi.org/10.9790/487X-2006023945

Zada, M., Yukun, C., \& Zada, S. (2019). Effect of financial management prctices on the development of small-tomedium size forest enterprises: insight from Pakistan. GeoJournal. https://doi.org/10.1007/s10708-01910111-4 